\title{
Emergency Remote Teaching: The Emerging Roles and Expanding Responsibilities of the Bangladeshi School Teachers at Primary Level During COVID-stricken Period
}

\author{
Renaissance Ahmed Sayma \\ Assistant professor, Department of English, Comilla University, Bangladesh
}

\begin{abstract}
The goal of this article is to look into the current state of "emergency remote teaching" and the effects of Covid19 on Bangladesh's primary education system. Bangladeshi School teachers started online classes few months after the compulsory closure of all educational institutions. This study sheds light on the changing roles of teachers during the pandemic situation, challenges of adaptation of online classes in both the rural and city areas, and the expanded responsibilities of the primary school teachers in terms of teachers' experiences. Fifteen potential primary school teachers were interviewed over the telephone, and 50 primary and secondary school teachers from 45 different schools in Bangladesh were surveyed over Google forms. The quantitative data were analyzed with Microsoft Excel and summary of Google form, and the thematic analysis approach had been kept for qualitative one. The findings revealed that primary education level teachers have already started online classes despite not having any formal training or experience. The good news is that the teachers feel an urge to develop their knowledge by taking help from their own schools' ICT teachers. The findings also revealed that most teachers are experiencing expanded responsibilities during the 'new normal life,' such as providing financial, moral, and psychological support to the students, maintaining a good relationship with guardians, and making them aware of the importance of online education. Even though few students have the facilities of digital resources and a friendly environment at home, they could not keep themselves engaged in the class. It is proved as one of the significant barriers of primary education level teachers. Students from rural areas and underprivileged urban areas are seen dropping out of school or engaging in child labor. Acknowledging the results, the study recommended some suggestions that might aid policymakers in eliminating the difficulties of remodeling the roles and responsibilities of the Bangladeshi school teachers at the primary level during the COVID-stricken period.
\end{abstract}

Keywords:Primary education, emergency remote teaching, online class, pandemic, Teachers' response, challenges, internet.

DOI: $10.7176 / \mathrm{JEP} / 12-21-07$

Publication date:July $31^{\text {st }} 2021$

\section{Introduction}

From a more comprehensive outlook, the educational system of Bangladesh is divided into three precise stages. These are Primary, Secondary, and Tertiary. Primary Education consists of primary and secondary school. High schools and Intermediate College is authorized under secondary Education. Further, Tertiary Education authorizes Universities and Degree Colleges. The Ministry of Primary and Mass Education (MOPME) was established in 1992 to manage Primary Education. MOPME is majorly concerned with the formulation of strategies. At the same time, the Implementation is managed by the Directorate of Primary Education (DPE). Headed by a DirectorGeneral, DPE and its subordinate offices in the districts and Upazila mainly supervise and manage the primary Education. They take responsibility for posting and transferring teachers and other staff, recruitment, distribution of free textbooks, and supervising schools. Two public examinations are arranged by The Directorate of Primary Education (DPE). Students from 5th grade sit for Primary School Certificate (PSC), and students from 8th grade sit for Junior School Certificate (JSC). Covid-19 struck the world at the beginning months of 2020. Soon, the educational institutes around the world were closed to restrict the expansion of the deadly pandemic. This closure massively damaged the world's 1.5 billion learning from pre-primary to upper secondary school students (UNESCO 2020).

In December 2019, when Wuhan identified an acute respiratory disease named coronavirus, no one ever thought it would hold the breath of the entire world. However, by the time it emerged as Covid-19, it took a thousand lives with a whopping number of 43 thousand cases. Nobody ever imagined a Nano virus would take control over the entire planet. Therefore, the world did not take appropriate steps to defend it from the deadly virus. After creating havoc on China, it started its rampage on Europe with Italy. In 47days, Italy overtook the death toll of China. In no time, it traveled with the European travelers to the USA. Soon it marked a devastating impact on the entire country and stood as the most affected country by far with $603 \mathrm{~K}$ deaths. Although it took a relatively considerable time to enter into the South-Asian region, it showed its deadly force with remodeled delta variant. Bangladesh identified its presence on 8th March 2020. By far, Bangladesh identified almost 9 lakh cases with almost 13 thousand death cases. The world was unprepared for this pandemic, and there was no vaccine to cure it. 
The only way to prevent the pandemic was imposing a stringent lockdown on the entire nation and arranging 14 days quarantine for travelers from abroad. Bangladesh followed the same way as other countries.

The Government of Bangladesh (GoB) didn't take too long to impose a strict lockdown. 17th March 2020, in a week of its arrival, the Government enforced lockdown to control the flow of the pandemic. The lockdown made a sudden and substantial impact on the educational institutes. Arguably the biggest harm Covid-19 made on the educational sectors. Since educational institutions are expected to be crowded in every country, it was essential to enforce the lockdown. Otherwise, it would spread rapidly, causing great harm to the future of the nations. Many policymakers did not want to avoid Education, so they got busy finding ways to fill up the substantial educational gap (Daniel, 2020). This pandemic pushed the think tanks of every country to find an alternate way to continue their educational sectors (Rahman, 2020). The roles of the teachers and the authorities have witnessed a massive change. New circumstances provided new problems, and new problems required new solutions. Since no one ever faced this situation, it was difficult for everybody to find a new outlook to handle the hindrance.

At first, students did not imagine the length of their detachment from their educational institutes will be so long. Therefore, they took it as a vacation, which later turned into an unending depression. This whole new circumstance had to be handled by some bold and intelligent decision in which the educational authorities and the teachers had to play a prominent part. The teachers now had to get careful about new teaching methods and deal with the newly aroused depression of the students. As the best alternative to usual face-to-face learning, emergency remote teaching is applied by using digital platforms. As a result, the Bangladeshi government is collaborating with UNICEF to create successful remote learning initiatives that reach the largest number of kids possible through the use of television, radio, Android phones, and online platforms (UNICEF, 2020). Online Education replaces the traditional classroom of blackboard into a virtual environment (Basilaia and Kvavadze, 2020). Besides UNICEF, the Ministry of Education (MoE) had also helped develop guides to support teachers for taking the class and minimize the losses of students to shun the gap (Alam, 2010). However, moving smoothly from a conventional educational environment to a virtual platform is not an easy task in a blink. However, the remarkable efforts by many institutions are a bright sign of affirmative hope for the possibility of change. Although Government enhanced its initiatives for the online classes, most of the unprivileged urban areas and the rural areas are having a troublesome time adopting this new process.

Soon after, the GoB instructed instructors to conduct primary school students' classes via television. In the aftermath of the lockdown, private institutions have hastened to embrace web-based learning methodologies, delivering lectures presented via online media stages (Chen et al., 2020). These initiatives of online Education are a massive boost for digitalization. However, the results are not a blessing to everyone. Most Bangladeshi primary and secondary schools are located in rural areas until class eight, according to the Ministry of Education. More than half of primary and secondary school students, according to reports, attend government-run schools, which are mostly located in rural areas. Digital equipment, experienced teachers, and sound facilities are all lacking in rural schools (Rafe, 2020). This has stymied efforts in our country to promote online learning.

This article aims to examine the current state of 'emergency remote teaching' and the issues associated with e-teaching so that policymakers may devise solutions to deal with the situation now and in the future. During Pandemic New Normal life, the teachers can decrease the educational gaps, their outlook over online Education, and problems regarding e-learning are also the principal aim of this study. Finally, during a pandemic, this research will give insight on the enhanced responsibilities of primary and secondary school teachers.

\section{Literature Review}

Due to the Covid-19 pandemic, the entire country was under strict lockdown, which made a critical impact on the students and the stakeholders connected to educational sectors. Online education was a damage control strategy for emergency response. It was crucial to reach out to all classes of students regardless of their place. Mediums like television, radio, and social platforms like Facebook, Zoom, Google classroom, Google meet was means of communication. Even though online education gives a firm system in a pleasant atmosphere, everyone in Bangladesh cannot afford it. It raises a question about how fine learners and educators in Bangladesh can conform to this new system.

The world's outdated teaching methods had to be upgraded as a result of the Covid-19 pandemic. Disaster remote learning refers to teaching from afar at all levels of education under a state of emergency. The situation was completely unexpected for everyone since the circumstance was offbeat from the well-planned traditional method to online learning. Nonetheless, well-planned online education is a complicated method.

Several difficulties and possibilities emerged in the social and technological field. It happened as a result of the transition from online to emergency remote instruction. This change had a significant influence on the children's physical and emotional wellbeing. Learning occurs through active engagement in a social context, according to the social constructivism idea. The closure of educational institutions has changed the role of home to a classroom setting. However, there will not be any physical and social interaction with the teachers and peers. This lack of interaction is regarded as a significant lapse because technology is the only means of interaction 
between teachers and other students. Parents and students were accustomed to the traditional mode of learning, face-to-face education.

It adds another feather to social-level challenges. The traditional method of teaching was suitable for those who faced hard times with having technological devices. However, in the current scenario, parents are providing digital technologies, and they are even learning to support their children. The pandemic situation enhanced obligations on the parents. The quality and quantity of online education can be influenced deeply by the experience parents achieve from emergency teaching in the future. To fill the research gap, this study encompasses a wide range group of parents whose children attend different grade levels in Primary and secondary schools in Bangladesh. Online learning is also influenced by the computer knowledge of teachers and students, instructional methods of teachers, administration's mindset, policy frameworks, and technical assistance (Srichanyachon, 2014)

The government of Bangladesh recognized the urge for teachers' professional education and training. They are regularly arranging ICT training for the teachers. Further, a sanctioned web portal named Shikkhok Batayon was opened so that all the teachers can collect their required content from a single source. However, taking an online class is new to most secondary teachers in Bangladesh because it is unprecedented. Starting online classes without preparation and proper pedagogy would be less interactive and ineffective. The teachers need to be skilled at ICT in both multimedia classes and online classes. The user of multimedia needs knowledge and experience about it as well as one or two multimedia software. But, in the online class, it is essential to know from where one can collect the materials they require and the process of using those for teaching and learning.

Moreover, knowing the way of presenting educational content on the online platform and using the multimedia product is vital. Most Bangladeshi primary and secondary school teachers have never been trained on these issues. As a result, the goal of this study is to determine secondary school teachers' perspectives toward taking online lessons during Bangladesh's Covid-19 pandemic lockdown. The government of Bangladesh has completed the construction of 24,816 multimedia classrooms. They connected about $90 \%$ of schools to the internet and set up a monitoring system for the multimedia classes. However, these infrastructures could not be utilized to take online classes as the schools are closed during the lockdown period. Arranging and conducting online classes for secondary education is tough in developing nations like Bangladesh. The gadgets require for online classes are expensive. Besides, the internet connection is not the same in all the areas. $60 \%$ of people of Bangladesh have internet access, and $92 \%$ of them use the mobile network for using the internet (BTRC, 2020). However, the internet speed varies widely in urban to rural areas (Sohail, 2020). Unfortunately, the gadgets required for participating in online classes are mostly out of most students' capability.

Recent studies affirm that many secondary education teachers started teaching online without any training or experience. Very few respondent teachers took online examinations and gave homework and assignments based on their performance. Teachers encounter various difficulties like a lack of digital equipment, expertise, unfamiliarity with the LMS, proficiency in assessment technique, etc.

The paper achieves with few suggestions such as providing fitting devices to the teachers and students so that they can participate in online classes. Promote austere training to magnify the teachers' technology-based skills and capabilities in order to get the expected upshot. Online learning is also influenced by the computer knowledge of teachers and students, instructional methods of teachers, administration's mindset, policy frameworks, and technical assistance (Srichanyachon, 2014). For joining online education, smartphones and a stable internet connection are essential for the students. Generally, families with low income do not have a single mobile phone, let alone smartphones. There is a clear distinction between rural and underprivileged urban areas with privileged urban areas in terms of accessing ICT platforms. The privileged urban area enjoys the fruits of ICT more than the rural and underprivileged urban area. Lack of access to gadgets, online resources, materials, and training poses a significant challenge to remote teaching. In contexts such as the USA, where computers and internet connectivity had already been integrated into most classrooms, it was relatively easy to introduce remote teaching by signing contracts with Zoom and other online platforms (Ndambakuwa \& Brand, 2020). However, the scenario is very different in developing nations. A large segment of the population in South-East Asia still does not have access to electronic devices and the internet (Jalli, 2020). There are infrastructural gaps between different parts of a country, resulting in discrepancies in internet speeds (Jalli, 2020). The teachers and the students have limitations and inadequacies over access to the internet.

In many underdeveloped nations, the cost of internet data packages is said to be a problem for students and teachers (Broom, 2020). Teachers in Bangladesh are paid low incomes, making it difficult for them to cover the costs of online classes (The Daily Star, 26 July 2020). The usage of older and outdated equipment may result in delays in accessing online information and a less enjoyable experience for participants (Beaunoyer et al., 2020). Institutions must ensure that the population has optimal access to technology in the current COVID-19 framework, reducing the effects of digital inequality, it has been discussed.

In the absence of regular face-to-face interaction and observation that most teachers are used to, teachers are expected to develop practical strategies to make online classes engaging and effective (Whittle et al.,2020). There have been reports of a lack of trust in online tests as cheating may be facilitated (ibid). 
During the current crisis, pandemic-induced restraints such as social distancing, home quarantine, and isolation impact family income and general well-being (Bhuiyan et al., 2020). These effects are reported to have been seriously felt among the students (Whittle et al., 2020) and the teaching professionals in a range of contexts (MacIntyre et al., 2020). The pandemic has added additional stressors like health concerns, travel restrictions, shortages of daily necessities, and uncertainties about the future to their existing workload (ibid). In such an environment, teachers in Bangladesh are likely to find it a challenge to focus on teaching and developing materials and assessment tools.

Rubina et al. (2020) focused on the impact of pandemics and challenges faced by the teachers of public universities. So this researcher tends to peep into the reality of primary and secondary school teachers' perceptions regarding newly shaped roles and responsibilities.

Until today, there have been many pieces of research about the effect of online education during a pandemic situation which focused on College level, public and private universities. Nevertheless, there is hardly any research on reshaping roles and expanding responsibilities of Teachers of Primary education level (class 1-8) during the covid-19 situation. Because the primary level of education in Bangladesh is based on two board exams, the PSC and the JSC, it is critical to understand the true picture of Online education, students' ability to accept it, instructors' new responsibilities, and parents' new role as monitors during this pandemic.

\section{Methods}

Data was collected from 50 teachers from 45 different government, non-government, and MPO primary and secondary schools (classes 1-8) around the country in mid-May to June 2021 for this qualitative study. The researcher selected teachers as respondents randomly from 18 different districts in Bangladesh via Google forms, emails, WhatsApp, and mobile phones. Also, the researcher contacted the most senior and potential school teachers over the phone and selected them based on their availability, gender, years of experience, and regional spread. After that, she conducted interviews via Zoom and telephone. This researcher selected most primary and secondary schools from rural areas and unprivileged urban areas to pick an accurate picture of Bangladesh's primary education. To compare, 15 schools were selected from the city area with adequate infrastructure and students from wealthy families who have their digital materials to adopt the new 'emergency remote learning quickly'. Most of the teachers had just started online classes, while some were about to begin their online classes. In this onlinebased survey, a well-structured questionnaire with 70 questions was designed, which contained some demographic characteristics and information about their knowledge on online teaching, online class experience, new teaching strategies, challenges of remote class managements, students as well as their parents' reactions, assessment during the pandemic time, expanded responsibilities of teachers. Questionnaire link was sent via Google Form to respondents through email and Facebook messenger. Before starting the survey, the aims, objectives, and the confidentiality of given responses were clarified with participants. The answer option was yes/no, short answers, click more than two or three points, agree/disagree, very often/never, and then why yes/no. Newspaper reports, online publications, and published journal articles were the source of secondary data. All of these were collected via internet browsing.

\section{Findings of Questionnaire}

In this following section, the findings from the teachers' survey and interviews had been shown.

\subsection{Demographic characteristics of the Participants Data}

A total of 50 questionnaires out of 75 were returned. The demographic data of the participants are demonstrated in Table 1. Of 50 participants, 63.6\% were female teachers, and 36.4\% were male teachers. 36.4 percent of the participants had 15 to 25 years of teaching experience. Teachers from rural areas made up two-thirds of the respondents, while the rest came from urban areas with privileged and disadvantaged locations. More than half of the teachers do not have any training on ICT, and very few of them (18.2\%) have previous experience in multimedia classes. The students whom they teach almost majority go for government school (59.1\%) only because of a sincere interest in Government scholarship and a minimum fee of school. Minimal 10.9\% of teachers were from a private school with many digital facilities. 
Table 1: The demographic profile of the teachers who were polled is as follows: $(\mathrm{N}=50)$

\begin{tabular}{|c|c|c|}
\hline Variables & options & Percentages \\
\hline \multirow[t]{2}{*}{ Gender/Sex } & Male & $36.4 \%$ \\
\hline & Female & $63.6 \%$ \\
\hline \multirow[t]{4}{*}{ Period of teaching experience } & Less than 10 years & $31.8 \%$ \\
\hline & $10-15$ years & $9.1 \%$ \\
\hline & $15-25$ years & $36.4 \%$ \\
\hline & More than 25 & $22.7 \%$ \\
\hline \multirow[t]{3}{*}{ Have training on ICT } & Yes & $54.5 \%$ \\
\hline & No & $40.9 \%$ \\
\hline & May be & Null \\
\hline \multirow{2}{*}{$\begin{array}{l}\text { Pre-pandemic experiences of } \\
\text { taking Multimedia class }\end{array}$} & No & $81.8 \%$ \\
\hline & Yes & $18.2 \%$ \\
\hline \multirow{3}{*}{$\begin{array}{l}\text { Pattern of primary and secondary } \\
\text { school }\end{array}$} & Government & $59.1 \%$ \\
\hline & MPO & $30 \%$ \\
\hline & Private & $10.9 \%$ \\
\hline \multirow[t]{2}{*}{ Area of School } & Rural & $72.7 \%$ \\
\hline & Urban & $22.7 \%$ \\
\hline
\end{tabular}

\subsection{Perception and Experience about 'Emergency Remote Teaching'}

Results given in table 2 show that the respondents' perception and experiences about 'emergency remote teaching' and online classes. Among the $86.1 \%$ of participants strongly think that online class is necessary for primary and secondary school level students. As they are almost dependent on teachers, these online classes will help them keep in touch with their studies and not lag. The majority of the respondents agree that they have started class from June to September 2020. They also mentioned that they got enough time to prepare for their classes, and $86.4 \%$ ensured the preparatory time was 7days. More than half of the participants said they didn't have access to laptops or desktop computers at home, and $78.2 \%$ said they utilized Android phones to conduct online lessons during the COVID-19 Pandemic. Despite having an idea about zoom class, the respondents agreed that most of them could not dare to take zoom class due to the lack of practical training. Whereas $45 \%$ of participants denied having any training, another $31.8 \%$ of enthusiastic participants were taking training from their respective schools' ICT teachers. Regarding the family environment for taking online classes, half of the respondents $(59.1 \%)$ agreed that they were getting proper space from household chores. This study finds that $36.4 \%$ of the participants had already taken more than 20 classes, but around $22.7 \%$ had not started any online classes yet. This researcher found that the estimated lecture times for online classes were less than 1 hour by $31.8 \%$ of the participants and $1-1.5$ hours by $36.4 \%$ of the participants. Very few, around $9.1 \%$ of them, gave more than 6 hours per week during the distance teaching. 59\% of the participants agreed that they were still developing and learning how to operate zoom platforms for taking online classes. Due to the high cost of the internet and unavailability of the network in remote areas, $54 \%$ of the teachers used mobile data while conducting their online classes during the emergency moment. 
Table 2: Perception about emergency remote teaching

\begin{tabular}{|c|c|c|}
\hline Variables & Options & Percentage \\
\hline \multirow[t]{2}{*}{ Do you think online classes are necessary? } & Yes & $86.4 \%$ \\
\hline & No & $13.6 \%$ \\
\hline \multirow[t]{4}{*}{ Starting date of online class } & March-May 2020 & $15 \%$ \\
\hline & June-September 2020 & $60 \%$ \\
\hline & October-December 2020 & $5 \%$ \\
\hline & January-June 2021 & $20 \%$ \\
\hline \multirow[t]{3}{*}{ Taking online classes regularly } & Yes & $50 \%$ \\
\hline & No & $45.5 \%$ \\
\hline & Did not like the process & $0.5 \%$ \\
\hline \multirow[t]{3}{*}{ Getting preparatory time for starting online classes } & Yes & $81.8 \%$ \\
\hline & No & $13.6 \%$ \\
\hline & May be & $4.6 \%$ \\
\hline \multirow[t]{3}{*}{ Preparation time before each class } & 1 week & $86.4 \%$ \\
\hline & 2 weeks & $9.1 \%$ \\
\hline & 1 month & $4.5 \%$ \\
\hline \multirow{2}{*}{$\begin{array}{l}\text { Do you have a desktop/laptop at home for taking } \\
\text { multimedia classes? }\end{array}$} & No & $72.7 \%$ \\
\hline & Yes & $27.3 \%$ \\
\hline \multirow[t]{3}{*}{ Electronic gadgets for taking online class } & Laptop/Desktop & $10 \%$ \\
\hline & Android Phone & $78.2 \%$ \\
\hline & Speakers and microphones & $11.8 \%$ \\
\hline \multirow[t]{2}{*}{ Are you familiar with zoom or Google class? } & Yes & $86.4 \%$ \\
\hline & No & $13.6 \%$ \\
\hline \multirow{4}{*}{ Training taken for online classes } & Peer training & $4.5 \%$ \\
\hline & Workshops & $18.2 \%$ \\
\hline & Schools' ICT teachers trained all & $31.8 \%$ \\
\hline & No training & $45.5 \%$ \\
\hline \multirow{3}{*}{$\begin{array}{l}\text { Your home provides you a friendly environment } \\
\text { for taking online classes }\end{array}$} & yes & $59.1 \%$ \\
\hline & no & $36.4 \%$ \\
\hline & sometimes & $4.5 \%$ \\
\hline \multirow[t]{5}{*}{ Number of online classes taken } & $<5$ & $22.7 \%$ \\
\hline & $6-10$ & $18.2 \%$ \\
\hline & $10-15$ & $18.2 \%$ \\
\hline & $15-20$ & $4.5 \%$ \\
\hline & $>20$ & $36.4 \%$ \\
\hline \multirow[t]{4}{*}{ Hours gave for online classes per week } & Less than $60 \mathrm{~min}$ & $31.8 \%$ \\
\hline & $60-90 \mathrm{~min}$ & $36.4 \%$ \\
\hline & $90-180 \mathrm{~min}$ & $22.7 \%$ \\
\hline & More than $180 \mathrm{~min}$ & $9.1 \%$ \\
\hline \multirow{3}{*}{$\begin{array}{l}\text { Efficiency in online teaching according to } \\
\text { teachers' perspectives }\end{array}$} & Efficient and satisfactory & $36.4 \%$ \\
\hline & Not efficient & $4.6 \%$ \\
\hline & Still developing and learning by the time & $59 \%$ \\
\hline \multirow{2}{*}{$\begin{array}{l}\text { Taking classes from home or school with better } \\
\text { equipped technological support }\end{array}$} & School & $22.7 \%$ \\
\hline & Home & $77.3 \%$ \\
\hline \multirow[t]{2}{*}{ Internet connection for online classes } & Wi-Fi & $45.5 \%$ \\
\hline & Mobile data & $54.5 \%$ \\
\hline
\end{tabular}

\subsection{Platforms uses for Remote Teaching}

The study found that respondent teachers were using several digital communicative platforms like Facebook live, messenger, WhatsApp, Zoom, etc., as their instructional media for online class; details are shown in figure 1. From the previous table, we found that they were developing their knowledge about online classes either by Government or by their interest. Upon analysis of interviews, this researcher also discovers that teachers from private universities started online classes just after the beginning of the shutdown in 2020. However, the teachers from the remote area started at the end of the $2020 \mathrm{~s}$. Among the participants, $81.8 \%$ of teachers used the zoom platform to keep continuing their interaction with students as well as lessons. $27.3 \%$ of them favored Facebook messengers to continue their classes surpassing their lacking of zoom operation. 


\section{Platforms uses during Online classes}

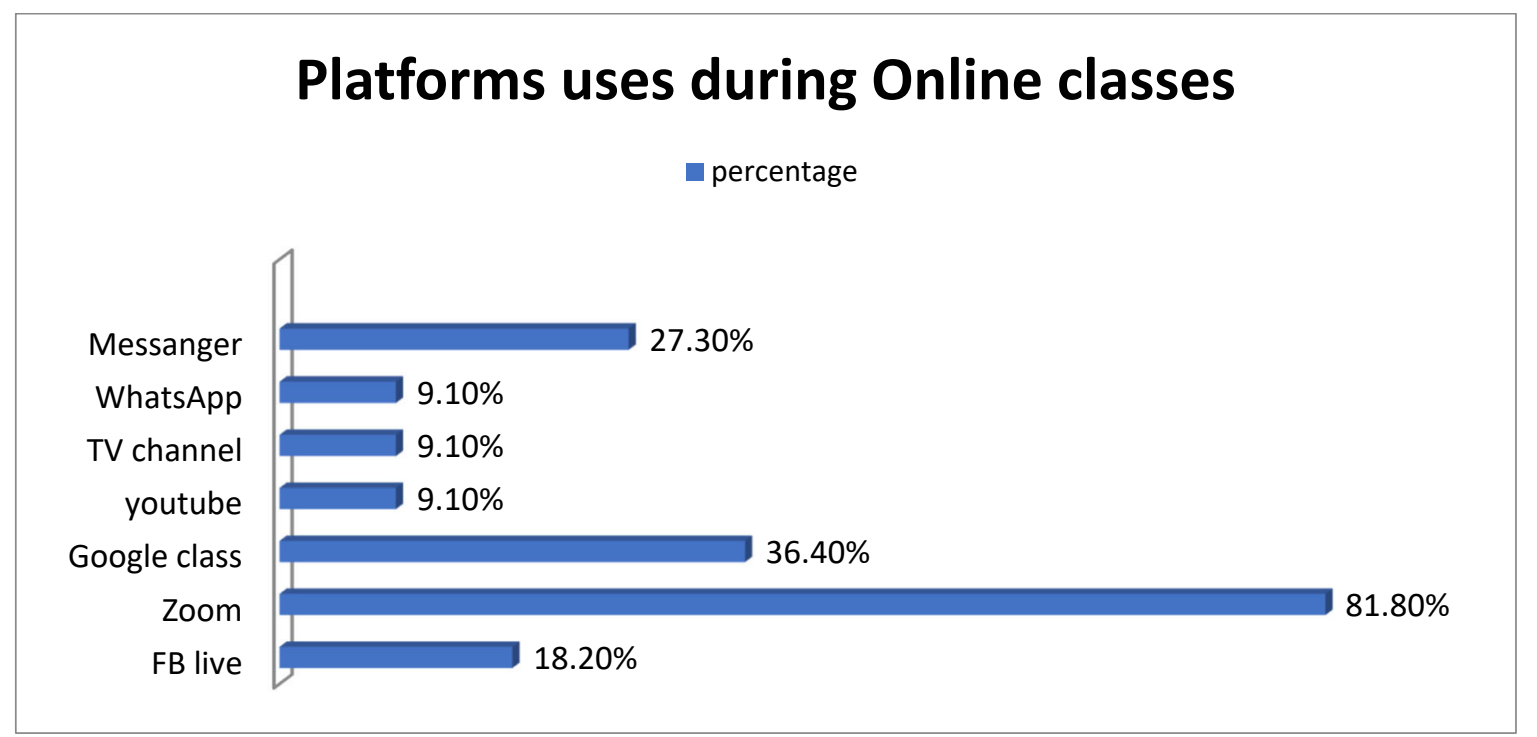

Figure 1: Usage of digital platforms for Emergency remote teaching

\subsection{Students Attendance and Response}

A class becomes fruitful by the sufficient presence of students. From table 3, this study finds that students struggled to adapt to the new learning approaches. Most of the time, they faced difficulties either by a technical issue, financial crisis, depression, or lack of interest in attendance and response. Half of the participants agreed that the students did not remain focused all the time from beginning to end. Also, the teachers observed that $50 \%$ of the students never response in the class, $18.2 \%$ of students often try to engage in the response session. The teachers opined that the response rate of the students was not satisfactory enough. $68.2 \%$ of them voted on the not satisfactory box. Around $60 \%$ of them declared that students were not adapting the online class methods very quickly. However, very few were claiming that the students were adapting the new remote learning method very swiftly. During this pandemic situation, the dropout from school was in the danger rank. Most of the teachers expressed their fear that the guardians had been encouraged to admit their children to Madrasa instead of encouraging them in online classes from oral interviews. This scenario is very common in primary and secondary schools, which were situated in remote areas. Two-thirds of the teachers expressed their sympathy for students who have already dropped out of school, and the percentage is approximately $80 \%$. This study also finds that the financial crisis and salary cut of their parents were the main hindrances behind such radical dropout scenarios in rural areas and underprivileged urban areas.

Table 3: Students' adaptation of online class

\begin{tabular}{|c|c|c|}
\hline Variables & Options & Percentages $(\%)$ \\
\hline \multirow{3}{*}{$\begin{array}{l}\text { Students remain focused all the } \\
\text { time }\end{array}$} & yes & $31.8 \%$ \\
\hline & no & $50 \%$ \\
\hline & sometimes & $18.2 \%$ \\
\hline \multirow{4}{*}{$\begin{array}{l}\text { Frequency of students response } \\
\text { observed by teachers }\end{array}$} & Very often & $22.7 \%$ \\
\hline & Often & $18.2 \%$ \\
\hline & Sometimes & $9.1 \%$ \\
\hline & Never & $50 \%$ \\
\hline \multirow[t]{4}{*}{ Attendance level of students } & Below $30 \%$ & $60 \%$ \\
\hline & $40-60 \%$ & $17 \%$ \\
\hline & $60-80 \%$ & $13 \%$ \\
\hline & Above $80 \%$ & $10 \%$ \\
\hline \multirow[t]{2}{*}{ Response of the students } & Satisfactory & $31.8 \%$ \\
\hline & Not satisfactory & $68.2 \%$ \\
\hline \multirow{3}{*}{$\begin{array}{l}\text { Students are adopting online } \\
\text { learning methods quickly }\end{array}$} & Yes & $40.9 \%$ \\
\hline & No & $31.8 \%$ \\
\hline & Not sure & $27.3 \%$ \\
\hline \multirow[t]{4}{*}{ Drop out percentage of your school } & $<10 \%$ & $59.1 \%$ \\
\hline & $10-30 \%$ & $22.7 \%$ \\
\hline & $30-60 \%$ & $9.1 \%$ \\
\hline & $>60 \%$ & $9.1 \%$ \\
\hline
\end{tabular}




\subsection{Challenges Related to Teacher-Students Interaction}

One of the principal contributory portions in pedagogy and quality education is student-teacher interaction. Sometimes the teachers feel reluctant to introduce online classes as an alternative to offline.

Throughout the interaction, students gradually grow up and enrich themselves with better knowledge. Figure 2 shows that $31.8 \%$ of respondents faced excessive academic pressure in remote teaching and $36.4 \%$ think that online tool was not friendly for teacher-student interaction. Besides, a large group of teachers $(40.9 \%)$ reported that lack of question-answer sessions was the reason behind effective interaction in online classes. Sometimes, the educational focus is on the practical parts of delivering online courses. It does not focus on generating and executing a support system for online learners. It may hinder the idea of 'emergency remote teaching' and 'online class.'

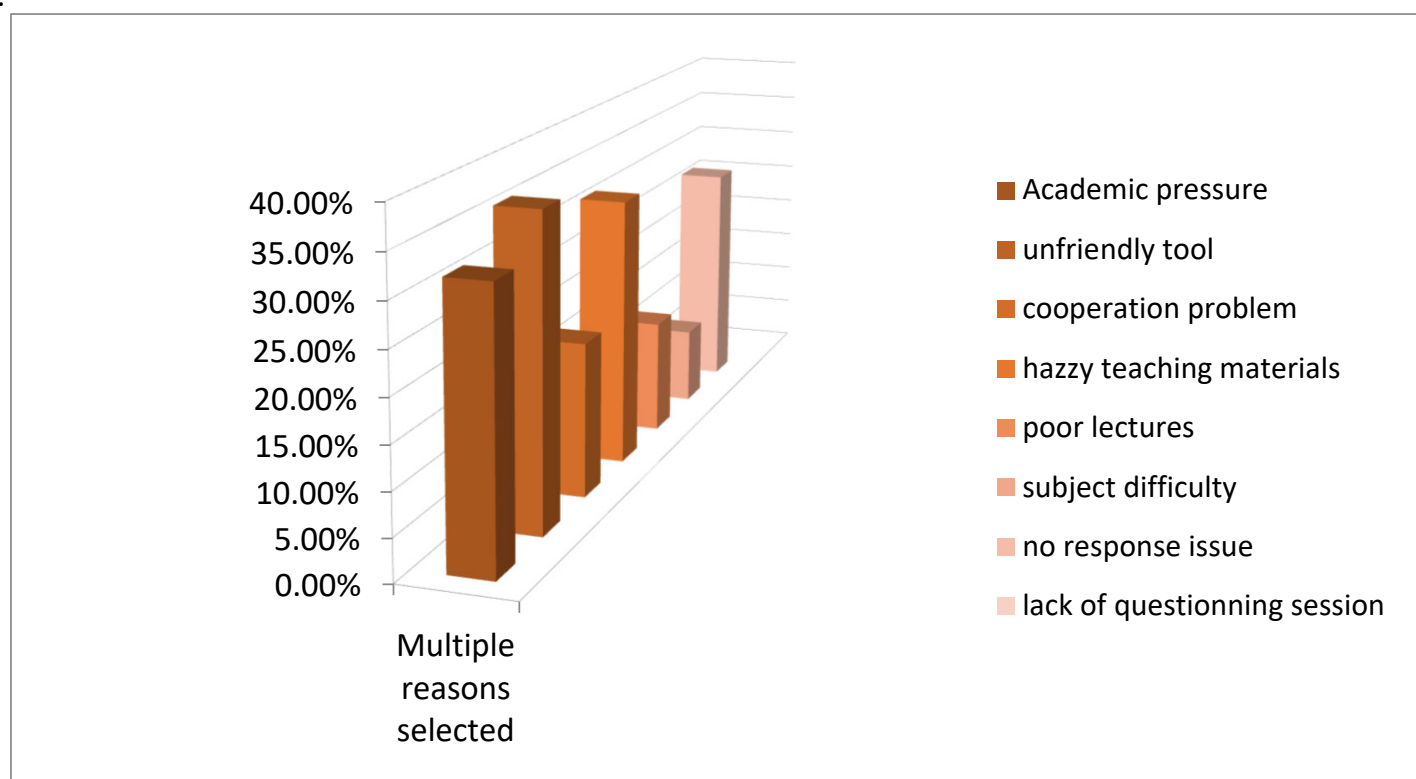

Figure 2: Interaction challenges

\subsection{Challenges Related to Teaching Aids}

Teachers use combinations of different teaching methods such as lecture, discussion, slide shares, collaborative tasks, etc., to conduct 'emergency remote teaching. Among these methods, the lecture method is the most popular $(55 \%)$ as derived from teachers' responses. Besides, $22.7 \%$ of teachers mentioned that they used lectures with slides shares, and $16.4 \%$ of teachers used slide shares only. Very few teachers (5.9\%) claimed to use the discussion method to elaborate their topics. Most of the teachers (68.2\%) mentioned that they never shared their lesson plan before the class to the students to get prior knowledge about the class. In both online and traditional programs, more than half of the teachers believed that they encouraged students to collaborate.

Table 4: Teaching aids of online classes

\begin{tabular}{|l|l|l|}
\hline Variables & Options & Percentages \\
\hline Share lecture materials before class & Always & $27.3 \%$ \\
\cline { 2 - 3 } & Sometimes & $4.5 \%$ \\
\cline { 2 - 3 } & Never & $68.2 \%$ \\
\hline \multirow{2}{*}{$\begin{array}{l}\text { Changed teaching methods during } \\
\text { the pandemic } \\
\text { (choosing more than two option } \\
\text { by each participant) }\end{array}$} & Only lecture & $55 \%$ \\
\cline { 2 - 3 } & discussion & $5.9 \%$ \\
\cline { 2 - 3 } & Slide shares with images or video & $16.4 \%$ \\
\cline { 2 - 3 } $\begin{array}{l}\text { Encouraging collaborative tasks in } \\
\text { online classes }\end{array}$ & Lectures with slide share & $22.7 \%$ \\
\cline { 2 - 3 } & Always & $68.2 \%$ \\
\cline { 2 - 3 } & Sometimes & $9.1 \%$ \\
\cline { 2 - 3 } & Never & $22.7 \%$ \\
\hline
\end{tabular}

4.7 Assessment Methods (Online exam/Assignment/Feedback)

During the closure of schools, scheduled class tests and half-yearly exams could not be arranged due to the pandemic 'New Normal life.' Without assessment, the teachers could not come to any conclusion about the progress of students' learning. In Bangladesh, the Ministry of Education announced a new assessment system, and 
that is assignment submission, and for each subject, the students got 7 days. It was recorded by $68.2 \%$ of the participants (Table 5) that they had not taken online tests, but $31.8 \%$ from the urban and city areas, teachers had already started taken online tests via zoom platform. From interviews, this researcher came to know that, few schools at the beginning took online tests where they provided the questions and answer sheet to the guardians and the guardians worked as a monitor during the exam at home. However, the teachers failed in monitoring whether the students were applying any unfair means or not. At the end of 2020 , the teachers mentioned that $63.6 \%$ of them followed the Government's instruction and assessed the students by students' submission of weekly assignments. Regarding feedback, $81 \%$ of teachers applied this appreciating approach to students in locating their progress. Teachers mentioned that feedback encourages students in the long run.

\section{Table 5: Online Assessment}

\begin{tabular}{|l|l|l|}
\hline Variables & Options & Percentages (\%) \\
\hline $\begin{array}{l}\text { Provide feedback on students' } \\
\text { assignment }\end{array}$ & Always & $81 \%$ \\
\cline { 2 - 3 } & Sometimes & $5.4 \%$ \\
\cline { 2 - 3 } & Never & $13.6 \%$ \\
\hline \multirow{2}{*}{ Have you taken online exams? } & yes & $31.8 \%$ \\
\cline { 2 - 3 } & no & $68.2 \%$ \\
\hline \multirow{2}{*}{$\begin{array}{l}\text { Approaches of assessing students } \\
\text { during the lockdown situation }\end{array}$} & $\begin{array}{l}\text { School system based on short } \\
\text { syllabus }\end{array}$ & $25 \%$ \\
\cline { 2 - 3 } & Govt. circulated assignment & $63.6 \%$ \\
\cline { 2 - 3 } & Could not fruitfully start yet & $11.4 \%$ \\
\hline Record progress of students & Yes & $81.8 \%$ \\
\cline { 2 - 3 } & No & $4.6 \%$ \\
\cline { 2 - 3 } & Sometimes Maybe & $13.6 \%$ \\
\hline
\end{tabular}

4.8 Challenges of Online Classes (Teachers own experiences and observation from students attendance)

Teachers are facing numerous challenges while taking online classes. Classroom management is one of the leading problems. $72.7 \%$ of the teachers claimed that 'emergency remote teaching' was the prime barrier in controlling the online classes. From table 6, this study also figured out several challenges that hindrance the spontaneity of online classes and remote teaching. Two-third of the participants mentioned that frequent shutdown of electricity was a significant challenge for them, the classes were disturbed frequently, and students became inattentive and demotivated. As the financial crisis is the undeniable factor during the lockdown situation, $80 \%$ of teachers accepted that students could not afford high-cost internet. Thus, they were forced to put themselves behind other classmates. This study found that most of the respondents were from rural areas; hence their students were also from low-income families, and the majority claimed that only $20 \%$ of students had their android phone to continue the classes. OtherThe respondents include another significant challenges are monitoring problems (59.1\%), passive learners (63.6\%), poor networking problem (86.4\%), limited class size (77.3), inability to focus on screen $(68.2 \%)$, lack of training experience $(72.7 \%)$, etc. Awareness of students' parents also contributed to emergency remote learning, and lack of awareness creates a barrier between teaching and learning. $40.9 \%$ of the teachers' assured that they found it awkward when sometimes guardians entered the online classes without maintaining any dress code or verbal behavior. In the zoom class, more than two-thirds of the teachers could not trace the presence of the students; sometimes, the students were seen busy online chatting or keeping video off; they went out of the classes. As a result, they were reluctant in case of answering or responding to teachers' queries. Last but not least, the rural and urban schools teachers found that their students were encouraged more by the guardians to attend or admit in the private coaching rather than be present in the online zoom class. The parents' attitude towards emergency remote teaching was not very satisfactory. This was up to now one of the major challenges that most of the teachers faced during the pandemic situation. 
Table 6: Challenges faced by stakeholders in online classes

\begin{tabular}{|c|c|c|}
\hline Variables & Options & Percentage $(\%)$ \\
\hline \multirow{2}{*}{$\begin{array}{lll}\begin{array}{l}\text { Difficult } \\
\text { management }\end{array} & \text { for } & \text { classroom } \\
& & \end{array}$} & Traditional, off-line class & $27.3 \%$ \\
\hline & $\begin{array}{l}\text { Emergency remote teaching, } \\
\text { online class }\end{array}$ & $72.7 \%$ \\
\hline \multirow{2}{*}{$\begin{array}{l}\text { Frequent shutdown of Electricity } \\
\text { problems }\end{array}$} & yes & $86.4 \%$ \\
\hline & no & $13.6 \%$ \\
\hline \multirow{2}{*}{$\begin{array}{l}\text { Students could not afford to buy } \\
\text { internet }\end{array}$} & Strongly agree & $80 \%$ \\
\hline & Strongly disagree & $20 \%$ \\
\hline \multirow[t]{3}{*}{ Students lack digital resources } & $20 \%$ & $36.4 \%$ \\
\hline & $20-50 \%$ & $31.8 \%$ \\
\hline & $>50 \%$ & $22.7 \%$ \\
\hline \multirow[t]{2}{*}{ Monitoring students } & Yes & $59.1 \%$ \\
\hline & No & $40.9 \%$ \\
\hline \multirow[t]{2}{*}{ Passive learners } & Yes & $63.6 \%$ \\
\hline & No & $36.4 \%$ \\
\hline \multirow{2}{*}{$\begin{array}{l}\text { Sudden arrival of students' family } \\
\text { members on screen }\end{array}$} & yes & $40.9 \%$ \\
\hline & no & $59.1 \%$ \\
\hline \multirow{2}{*}{$\begin{array}{llll}\begin{array}{l}\text { Difficult } \\
\text { presence }\end{array} & \text { to ensure students' } \\
\end{array}$} & yes & $85 \%$ \\
\hline & no & $15 \%$ \\
\hline \multirow{2}{*}{$\begin{array}{l}\text { Limited class size, not enough for } \\
\text { completing lesson }\end{array}$} & yes & $77.3 \%$ \\
\hline & no & $22.7 \%$ \\
\hline \multirow[t]{2}{*}{ Poor mobile network } & yes & $86.4 \%$ \\
\hline & no & $13.6 \%$ \\
\hline \multirow{2}{*}{ High cost of data package } & yes & $63.6 \%$ \\
\hline & no & $36.4 \%$ \\
\hline \multirow{2}{*}{$\begin{array}{l}\text { Inability to focus on the screen for } \\
\text { a long time }\end{array}$} & Agree & $68.2 \%$ \\
\hline & Disagree & $31.8 \%$ \\
\hline \multirow{2}{*}{$\begin{array}{lll}\text { Lack of adequate training } \\
\text { experience }\end{array}$} & Have training & $27.3 \%$ \\
\hline & No training & $72.7 \%$ \\
\hline \multirow{4}{*}{$\begin{array}{l}\text { Students parents negative attitude } \\
\text { towards online education }\end{array}$} & Strongly agree & $27.3 \%$ \\
\hline & Agree & $36.4 \%$ \\
\hline & Neutral & $22.7 \%$ \\
\hline & Strongly disagree & $13.6 \%$ \\
\hline $\begin{array}{l}\text { Students don't possess their own } \\
\text { android phones }\end{array}$ & Agree with & $68.2 \%$ \\
\hline $\begin{array}{l}\text { Students are interested more in } \\
\text { coaching classes }\end{array}$ & Agree with & $70 \%$ \\
\hline
\end{tabular}

\subsection{Barriers of Online Assessment}

Challenges related to online assessment included construction and administration of online tests, providing feedback, issues of reliability and plagiarism, and the existing examination system. The majority of the participants (70\%) mentioned cheating and plagiarism (Table 7) as barriers to successfully delivering online tests in the COVID-19 Pandemic. In the rural areas, hardly one phone is available in the family, and it became tough for the teachers to reach all of the students in time. The survey also found that $75 \%$ of teachers claimed that both parents had to go to work; there would not be anyone to control the students. Although the social distance is essential in controlling the spread of the virus, this could not provide an environment of the school in the rural families where $65 \%$ of teachers mentioned that this is another major setback of online assessments. On the contrary, guardians were seen as very friendly and cooperative regarding online assessment in private schools. They provided a suitable environment for participating in classes as well as the exams. 
Table 7: Barriers of online assessment

\begin{tabular}{|l|l|}
\hline Variables & Percentages \\
\hline Construction and administration of online tests & $59.1 \%$ \\
\hline Chance of unfair means & $70 \%$ \\
\hline Guardians are not serious regarding online exam & $30 \%$ \\
\hline plagiarism & $22.7 \%$ \\
\hline Guardians go for work with taking the android phones & $75 \%$ \\
\hline Home does not provide exam environment & $65 \%$ \\
\hline Discouragement getting from parents & $30 \%$ \\
\hline Could not reach all students over the phone & $65 \%$ \\
\hline
\end{tabular}

\section{Data Analysis from Open-ended Questions Interviews}

Expanded Responsibilities of Primary and Secondary School teachers during Pandemic situation:

Like everyone else, teachers and guardians were shocked after hearing the news of the shutdown of schools suddenly due to the epidemic going out of hand. The sudden outbreak of the pandemic has taken its toll on the educational system. In a student's life, the role of a teacher is indispensable. Children receive their emotional needs from home, while it is the teachers who recognize and understand them at school. The teachers nourish the children for a bright future. Alternatively, the teachers play the role of 'parents' in the school.

This researcher finds noteworthy differences between the pre-pandemic and during the pandemic role of a teacher from the interview. From the traditional blackboard and offline classes, the role of the teacher shifted to distant learning using digital resources. The teacher played the role of a lecturer or a class teacher who rigidly monitors the students' classroom performances before the pandemic. Now, post-Covid, the teacher had to play an entirely different role. In the 'emergency remote teaching' era, the teachers became more creative, fun-loving, and friendly. Again, as they had to run the online classes from their home, there had a dramatic change in the balance between work and personal life.

After asking whether they had experienced any significant changes in their responsibilities during COVID19 , more than $80 \%$ of them mentioned they earned several expanding responsibilities towards students.

\subsection{Financial Support}

From figure 3, this study finds that $72.7 \%$ of the teachers helped their students personally so that they could not mingle with the wrong company during the loss of finance. $4.6 \%$ of teachers mentioned that they sometimes tried to provide financial support to the students coming from destitute families. However, $22.7 \%$ of teachers also mentioned that they did not involve helping issues and did not consider this as their expanding responsibilities during the Covid-19 pandemic situation.

\section{financial support}
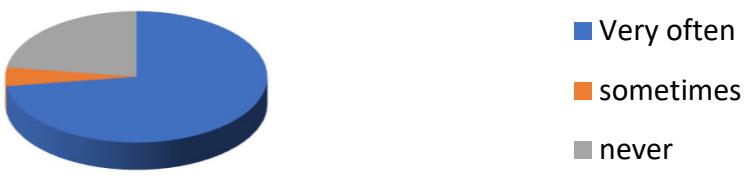

Figure 3: Provide financial support

\subsection{Creating Awareness among Parents of the Students}

From the interview over the mobile phone, the researcher happened to find out several reasons behind parents' negative attitudes and found the $70 \%$ of the participants who felt an urge to discuss the problems with the parents to make them aware of the importance of online education and assessment. Around $75 \%$ of the participants assumed that money was the root cause of all the parents' negative attitudes, especially from the rural and underprivileged urban schools. Financial problems $(65 \%)$, the inadequacy of electronic devices $(85 \%)$, low socioeconomic status $(80 \%)$, children' addiction to games on phones $(75 \%)$, young girls and boys from class $5-8$ became engaged in a relationship (52\%), parents were not serious about online assignments (40\%) were estimated as the major issues for the discouraging attitudes of parents towards students as well as online classes. So, the teachers felt it their responsibility to make the parents aware of 'Emergency remote Teaching.' Most of the teachers from rural and urban areas mentioned they called each of the students over the phone and took care of their every needs and problem. By doing so, parents and teachers had created a bridge between them. 


\subsection{Psychological and Moral Counseling to Students}

Covid-19 is not a normal situation. So, every role and responsibility is bound to be reshaped and expanded. Teachers are not out of the expectation. From the interview survey, it is found that after the closures of schools, every teacher became the course teacher with a mission to counsel the students every minute and to help them to get rid of depression, anxiety, psychological breakdown, etc. In this regard, the elderly teachers were found more responsible and caring to their expanded responsibilities. $65 \%$ of the participants strongly agreed that they discovered an expanded responsibility of counseling each student during the covid-19 situation. One of the female teachers from rural areas cried out of frustration, "When I reached the school and got down from the auto, it is a matter of great sorrow that, I witness two-third of my students are working as an assistant in the village vegetable market."

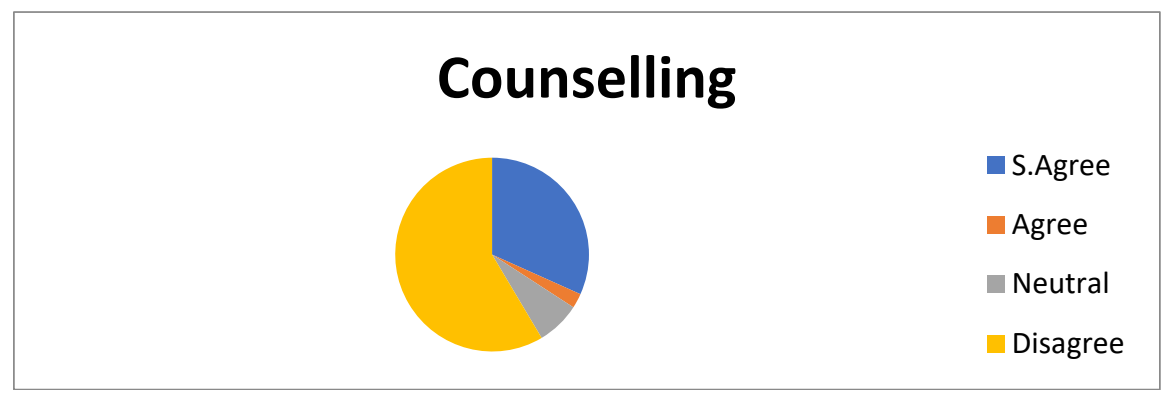

Figure 4: Counseling

\subsection{Health Awareness}

While giving the interview, the teachers disclosed that they taught the students about hygiene in online classes. Both the rural and urban school teachers warned the students about the dangerous side of coronavirus and the ways to fight against the virus. Few teachers $(40 \%)$ ensured the researcher that they provided masks and sanitizer to the students and thus created awareness among the primary and secondary schools' students.

\subsection{Provide Printed Assignments}

As most students are from low-income families who could not afford to manage an android phone to attend the classes and buy high-cost internet, the primary and secondary school teachers contributed a voluntary responsibility toward poor students. To motivate students in the pandemic situation, most of the teachers $(55 \%)$ download and printed the assignment instructions (figure 5) from government web addresses and provided the assignment instructions copy to the parents" of the students.

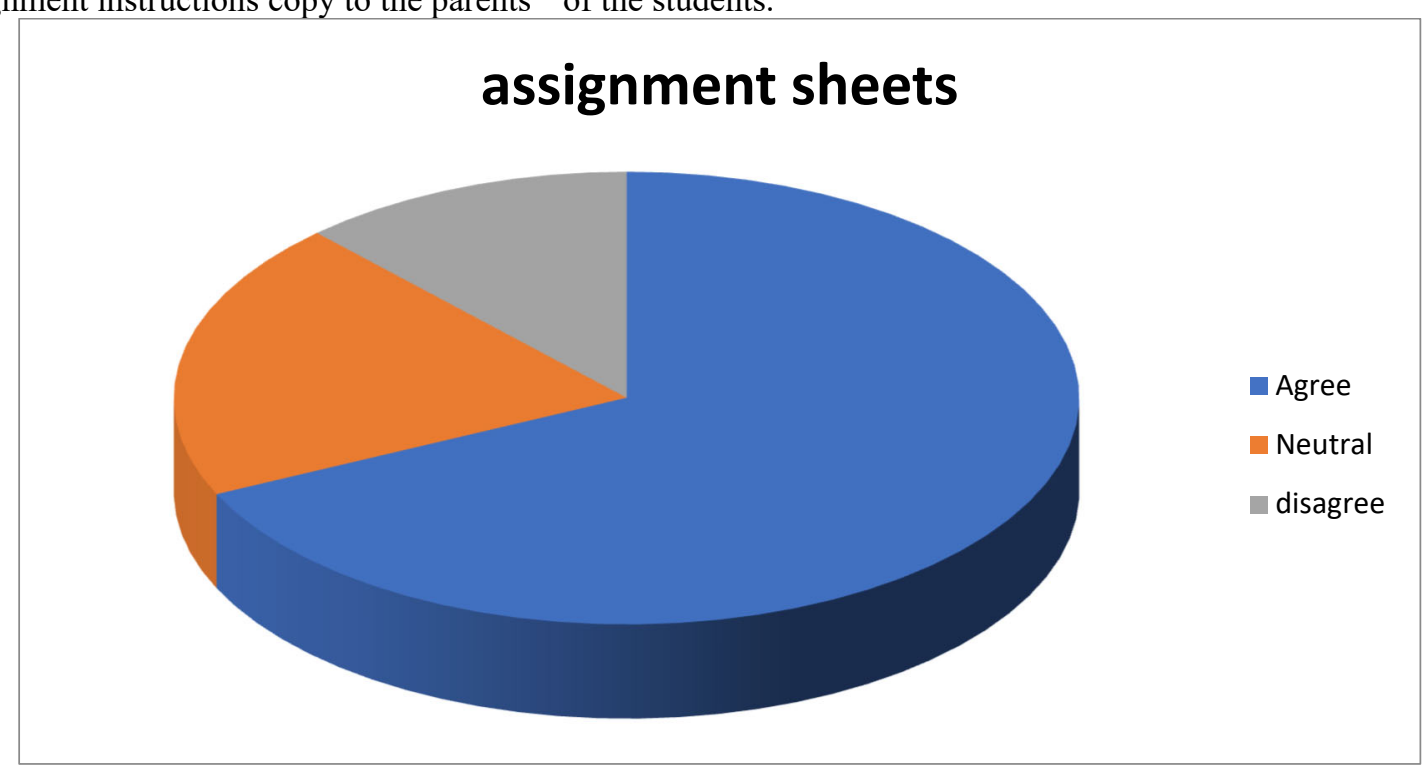

Figure 5: Provide Printed Assignments

5.6 Personal Contact and Visit to Students Home

To maintain a good relationship with students and guardians, during covid-19 situations, most of the teachers ( $45 \%)$ mentioned they went to students' homes every month and attempted to counsel them. On the contrary, the teachers from privileged city areas used to keep communication over telephone or zoom meeting with parents. 


\subsection{Personal Life and Work-life balance}

The harmony in their family life fell apart from the survey as they had to include the office work in the home. However, most of the participants (51\%) looked at this change as their 'New Normal life,' and they were adapting this change with the hope of better life ahead.

\section{Conclusion and Recommendation}

The study evaluated at the present emergency remote teaching and learning scenario in Bangladesh's primary school system during the Covid-19 pandemic (classes 1-8). The study's findings suggest that developing a robust pedagogy without prior training experiences and workshops is challenging. Limited and challenges encountered by teachers of primary and secondary schools in taking online classes can be mitigated by institutional and GoB support. These supports are also needed to minimize the imbalance of quality of traditional face-to-face primary education versus emergency remote teaching and help both the stakeholders cope with the inconvenience of the sudden transition of the teaching-learning platform. Finally, the study could forecast that online classes started due to pandemics might not be a transitional phase only. Instead, it might emerge as a new standard platform of education at primary education (class 1-8) for preparing the students of digital Bangladesh.

To ease up the significant difficulties outlined by both the students and teachers, the Government of Bangladesh may increase the speed of the internet for educational purposes within the affordable reach of teachers and students. To prompt enhancement of teaching-learning activities, Government may offer a soft loan to buy android phones. To ensure quality education and build the backbone of a nation, providing sufficient training for primary and secondary school teachers is a must. Participants advised that teachers and students should be given training in order to improve their technology skills. Besides, they stressed the importance of developing the appropriate infrastructure for online instruction. The interview survey noted that students need to be provided with emotional and psychological support and counseling. This researcher thinks that the teachers should motivate the students to join the online classes, and teachers should apply creativity and fun-game in their remote teaching method.

\section{References}

Alam, A. (2020). Challenges and possibilities of online Education during Covid-19. Retrieved 30April, 2021 from http:// www. Preprints.org/manuscript/202006.0013/v1.

Basilaia, G., \& Kvavadze, D. (2020). Transition to Online Education in Schools during a SARS-CoV-2 Coronavirus (COVID-19) Pandemic in Georgia. Pedagogical Research, 5, 1-9. https://doi.org/10.29333/pr/7937

Beaunoyer, E., Dupéré, S., \& Guitton, M. J. (2020). COVID-19 and digital inequalities: Reciprocal impacts and mitigation strategies. Computers in Human Behavior. doi: 10.1016/j.chb.2020.10642

Bhuiyan, A. I., Sakib, N., Pakpour, A. H., Griffiths, M. D., \& Mamun, M. A. (2020). COVID-19-related suicides in Bangladesh due to lockdown and economic factors: Case study evidence from media reports. International Journal of Mental Health and Addiction. doi: 10.1007/s11469-020-00307-y

Broom, D. (2020). Coronavirus has exposed the digital divide like never before. Retrieved from https://www.weforum.org/agenda/2020/04/coronavirus-covid-19-pandemic-digital-divide-internet-databroadband-mobbile/

BTRC. (2020, April 20). Internet-subscribers-bangladesh-march-2020. Retrieved June 21, 2021, from Bangladesh Telecommunication Regulatory Commission: http://www.btrc.gov.bd/content/internetsubscribers-bangladesh-march-2020

Chen, T., Peng, L., Yin, X., Rong, J., Yang, J., \& Cong, G. (2020). Analysis of user satisfaction with online education platforms in China during the COVID-19 pandemic. Multidisciplinary Digital Publishing Institute, Vol.8, No. 3, p.200.

Daniel, J. (2020). Education and the COVID-19 pandemic. Prospects, 49(1), 91-96.

Jalli, N. (2020). Lack of internet access in Southeast Asia poses challenges for students to study online amid COVID-19 pandemic. The Conversation. Retrieved from https://theconversation.com/lack-of-internetaccess-in-southeast-asia-poses-challenges-for-students-to-study-online-amid-covid-19-pandemic-133787

Khan, R., et al. (2020). Emergency Online Instruction at Higher Education in Bangladesh during COVID-19: Challenges and Suggestions. The Journal of Asia TEFL. http://dx.doi.org/10.18823/asiatefl.2020.17.4.26.1497

MacIntyre, P. D., Gregersen, T., \& Mercer, S. (2020). Language teachers' coping strategies during the Covid-19 conversion to online teaching: Correlations with stress, wellbeing and negative emotions. System. doi: 10.1016/j.system.2020.102352

Ndambakuwa, S., \& Brand, G. (2020). Commentary: Many students in developing countries cannot access education remotely. https://harris.uchicago.edu/news-events/news/commentary-many-students-developingcountries-cannot-access-education-remotely. Accessed on 22 June 2021. 
Rafe, R. (2020). COVID-19 deepens divide between Bangladesh's rural and urban students. (2020). Retrieved 30 May,2021, from http://www.dw.com/en/education-bangladesh/a-55358552

Rahman, M., Aziz. U., \& Ahmed, S. O. (2020). COVID-19 boosts digitalization of higher education in Bangladesh. Retrieved 20 May, 2021, from http://blogs.worldbank.org/endpovertyinsouthasia/Covid-19-boostsdigitalization-higher-education-bangladesh.

Sohail, E. (2020, April 10). Remote learning in the time of Covid-19 and beyond. Dhaka Tribune.

Srichanyachon, N. (2014). The Barriers and Needs of Online Learners. Turkish Online Journal of Distance Education 15(3), 50-59.

The Daily Star. 26 July 2020. Editorial. Retrieved from https://www.thedailystar.net/editorial/news/ ensureaffordable-internet-students-teachers-1936121

UNESCO (2020), Education: From Disruption to Recovery. Retrieved 30April, 2021, from http:// en.unesco.org/covid19/educationresponse

Whittle, C., Tiwari, S., Yan, S., \& Williams, J. (2020). Emergency remote teaching environment: A conceptual framework for responsive online teaching in crises. Information and Learning Sciences, 311. doi:10.1108/ILS-04-2020-0099

Renaissance Ahmed Sayma is an assistant professor of the Department of English at Comilla University in Bangladesh. Her research interest includes Postcolonial Literature, Education policy, and Applied Linguistics, TESOL, Psycholinguistics, Marxism and Feminism. 